\title{
ANALISIS RASIO PROFITABILITAS TERHADAP PENDAPATAN LABA CV. DELTA AGUNG PRATAMA PERIODE TAHUN 2013-2015
}

\author{
Ridwansyah Muharam, Jhon Fernos \\ Akademi Keuangan Perbankan "Pembangunan" Padang \\ Jhonfernos@akbpstie.ac.id
}

\begin{abstract}
Level of calculation using Net profit margin is the ratio of comparison between net income after tax and sales The amount of calculation of net profit margin shows how much profit after tax is obtained by the company for a certain level of sales in the financial statements of CV.Delta Agung Pratama. 2013 amounted to 0.16. In 2014 it decreased by 0.05 so that the company's margin became 0.11. In 2015 there was an increase of 0.02 so that the company's profit margin was 0.13 . When compared with the industry average ratio the company is classified as poor. Because the company's profit margin is below the industry average. The industry average is 0.2. The greater the ratio obtained by the company, the better, if the smaller the ratio obtained by the company, the worse because the company is considered unable to create a high enough profit from its sales activities.The level of calculation using ROI (Return On Investments) reflects the ability of management in managing its assets as optimally as possible so that the desired net profit can be achieved in the financial statements of CV.Delta Agung Pratama In 2013 the company's ROI was 0.29. In 2010 the company's ROI decreased by 0.10 so that the company's ROI became 0.19 In 2015 the company's ROI began to increase by 0.04 so that the company's ROI became 0.23. When compared with the average industry the company is classified as poor, because it is already below the industry average ratio. The ratio of the industry average is 0.3. So the higher the level of asset turnover, the higher the profit that will be obtained by the company, on the contrary So the lower the asset turnover, the lower the profit that will be obtained by the company The level of calculation using ROE (Return On Equity) is a ratio that shows the company's ability to generate net income by using its own capital and generating net income available to owners or investors in the 2013 financial statements of CV.Delta Agung Pratama showing a figure of 16, 56 which means that the level of income from invested capital generates a profit of 16.56. In 2014, this ratio has decreased considerably, amounting to 15.86 to 0.7, which means the level of income from invested capital generates a profit of 0,7 This decrease was due to the decrease in the company's net income of Rp. 38,526,000 In 2015, this ratio has decreased again by 0.14 to 0.56, which means that the level of income from the divested capital produces a profit of 0.56 The decline in the value of this ratio is due to a substantial increase in own capital compared to the increase in profit net. From the company's ROE calculation that occurred from 2013 to 2015, it can be seen that the company's ROE continues to decline every year. The decrease in the value of ROE that is clearly seen is in 2014 as many as 15.85, but the company's performance can still be said to be good because the company does not suffer losses from it. If you see the overall results that have been studied based on the profitability ratio of the company CV. DELTA AGUNG PRATAMA tends to fluctuate and is not stable most profitability ratios are below the average industry ratio that has been set, it can be said that the company's performance belongs to the category of poor and does not meet industry average standards
\end{abstract} Keywords: Bank, Financial Performance, Financial Ratio 


\section{PENDAHULUAN}

Perkembangan perekonomian pada masa sekarang ini menunjukkan perkembangan yang semakin pesat sekaligus menyebabkan tingginya tingkat persaingan usaha. Kondisi demikian menuntut pihak perusahaan agar dapat meningkatkan pengelolaan usahanya. Dalam hal ini pihak perusahaan perlu mengikuti perkembangan usaha secara global dan terus melakukan perbaikan dan menyempurnakan dalam bidang usahanya. Perusahaan yang kuat akan bertahan hidup sebaliknya perusahaan yang tidak mampu bersaing akan mengalami kebangkrutan.

Perkembangan dunia usaha di Indonesia yang semakin kompetitif menuntut setiap perusahaan untuk dapat mengolah dan melaksanakan manajemen perusahaan menjadi lebih profesional. Bertambahnya pesaing disetiap saat, baik pesaing yang berorientasi lokal maupun pesaing yang berorientasi international (multinational corporation), maka setiap perusahaan harus berusaha menampilkan yang terbaik, baik dalam segi kinerja perusahaan, juga harus ditunjang dengan strategi yang matang dalam segala segi termasuk dalam manajemen keuangan. Bidang keuangan merupakan bidang yang sangat penting dalam suatu perusahaan. Baik perusahaan yang berskala besar maupun kecil akan memberikan perhatian yang sangat besar dalam bidang keuangan ini. Terutama demi meningkatkan daya saing dengan perusahaan-perusahaan lain. Suatu perusahaan akan selalu terus meningkatkan posisi keuangan perusahaannya supaya dapat terus eksis dan mempunyai daya saing yang tinggi

Manajemen keuangan sangat berpengaruh terhadap kelangsungan kegiatan dan eksistensi suatu perusahaan serta berpengaruh pula pada setiap individu yang ada dalam perusahaan tersebut. Oleh karena itu, seorang manajer keuangan dituntut untuk dapat menjalankan manajemen keuangan dengan baik, hal ini dilakukan agar perusahaan dapat melaksanakan kegiatan operasional perusahaan dengan lebih efektif dan efisien, sehingga perusahaan dapat mengembangkan dan mempertahankan aktivitas serta keberadaan perusahaan.

Selain manajemen yang baik, perusahaan juga membutuhkan alat ukur keuangan yang digunakan untuk menilai kemampuan perusahaan dalam mengatasi masalah-masalah keuangan, mengambil keputusan yang cepat dan tepat untuk tahun mendatang, serta kekuatan keuangan (financial strength) melalui rasio keuangan yang dihitung berdasarkan data laporan yang dimiliki perusahaan. Laporan keuangan yang lengkap menurut Standar Akuntansi Keuangan terdiri dari komponen-komponen berupa : neraca, laporan rugi laba, laporan perubahan ekuitas, laporan arus kas dan catatan atas laporan keuangan. Selain berguna bagi perusahaan dan manajemennya, perhitungan rasio keuangan juga diperlukan oleh pihak-pihak yang berkepentingan lain seperti kreditor, investor dan pemerintah untuk menilai kondisi keuangan perusahaan dan perkembangan dari perusahaan tersebut.

CV. Delta Agung Pratama yang bergerak dalam bidang jasa dan penyediaan memiliki tujuan agar dapat menjadi sektor usaha yang dapat menghasilkan produk jasa yang bermutu dan profesional. Oleh karena itu Cv. Delta Agung Pratama dituntut untuk mampu menilai kondisi dan perkembangan perusahaan melalui rasio-rasio keuangan agar dapat mempertahankan keberadaan perusahaan dan mampu meningkatkan pertumbuhan perusahaan ditengah pertumbuhan ekonomi yang semakin pesat dan persaingan usaha yang semakin 
ketat. Penggunaan tahun 2013 sampai dengan tahun 2015 sebagai tahun objek penulisan dikarenakan pada setiap penulisan dibutuhkan data terbaru terkait tahun penulisan agar informasi yang disampaikan pun terbaru. Hasil yang lebih akurat akan didapatkan pada suatu penulisan deskriptif kuantitatif dengan tahun objek penulisan hingga Tiga tahun serta laba bersih CV. DELTA AGUNG PRATAMA yang secara garis besar mengalami pertumbuhan yang kurang baik pada tahun 2013 hingga tahun 2015.

Tabel 1

Data perhitungan Rasio profitabilitas CV. Delta Agung Pratama Tahun $2013-2015$

\begin{tabular}{lccc}
\hline \multicolumn{1}{c}{ Ratio profitabilitas } & 2013 & 2014 & 2015 \\
\hline Net profit margin & 0,16 & 0,11 & 0,13 \\
Return on investment & 0,29 & 0,19 & 0,23 \\
Return on equity & 16,56 & 0,7 & 0,56 \\
\hline
\end{tabular}

Sumber : CV. Delta Agung Pratama, data diolah

Berdasarkan tabel diatas dalam laporan keuangan CV.Delta Agung Pratama dalam perhitungan dengan menggunakan Net profit margin Dimana margin laba pada tahun 2013 adalah sebesar 0,16 Pada tahun 2014 mengalami penurunan sebesar 0,05 sehingga margin perusahaan menjadi 0,11 . Pada tahun 2015 mengalami kenaikan sebesar 0,02 sehingga margin laba perusahaan menjadi 0,13. perhitungan dengan menggunakan ROI ( Return On Invesment ) mencerminkan kemampuan manajemen dalam mengatur aktiva-aktivanya seoptimal mungkin sehingga dicapai laba bersih yang diinginkan dalam laporan keuangan CV.Delta Agung Pratama Pada tahun 2013 ROI perusahaan sebesar 0,29. Pada tahun 2014 ROI perusahaan menurun sebesar 0,10 sehingga ROI perusahaan menjadi 0,19 Pada tahun 2015 ROI perusahaan mulai naik sebesar 0,04 sehingga ROI perusahaan menjadi 0,23 perusahaan tahun 2013 menunjukkan angka sebesar 16,56 yang berarti bahwa tingkat penghasilan dari modal yang diinvestasikan menghasilkan laba sebesar 16,56

Pada tahun 2014, rasio ini mengalami penurunan yang cukup besar yaitu sebesar 15,86 menjadi 0,7 yang berarti tingkat penghasilan dari modal yang diinvestasikan menghasilkan laba sebesar 0,7

Pada tahun 2015, rasio ini kembali mengalami penurunan yaitu sebesar 0,14 menjadi 0,56 yang berarti tingkat penghasilan dari modal yang diivestasikan menghasilkan laba sebesar 0,56 .terlihat bahwa ROE perusahaan tahun 2013 menunjukkan angka sebesar 16,56 yang berarti bahwa tingkat penghasilan dari modal yang diinvestasikan menghasilkan laba sebesar 16,56

Pada tahun 2014, rasio ini mengalami penurunan yang cukup besar yaitu sebesar 15,86 menjadi 0,7 yang berarti tingkat penghasilan dari modal yang diinvestasikan menghasilkan laba sebesar 0,7

Pada tahun 2015, rasio ini kembali mengalami penurunan yaitu sebesar 0,14 menjadi 0,56 yang berarti tingkat penghasilan dari modal yang diivestasikan menghasilkan laba sebesar 0,56.

Dari data dan latar belakang yang telah diuraikan diatas maka penulis 
tertarik membuat penulisan tugas akhir dengan judul "Analisis Rasio Profitabilitas Terhadap Pendapatan Laba Cv. Delta Agung Pratama Periode Tahun 2013-2015".

Berdasarkan latar belakang masalah yang telah dijelaskan sebelumnya, maka permasalahan yang akan dibahas dalam penulisan ini ADALAH BAGAIMANA Analisis Rasio Profitabilitas Terhadap Pendapatan Laba Cv. Delta Agung Pratama Periode Tahun 2013-2015

Berdasarkan rumusan masalah yang telah dijelaskan sebelumnya, maka tujuan penelitian ini untuk mengetahui Analisis Rasio Profitabilitas Terhadap Pendapatan Laba CV. Delta Agung Pratama Periode Tahun 2013-2015

\section{LANDASAN TEORI}

\section{Pengertian Laporan Keuangan}

Akuntansi merupakan suatu sistem informasi yang memberikan keterangan mengenai data ekonomi untuk pengambilan keputusan bagi siapa saja yang membutuhkannya. Dalam akuntansi, informasi yang dimaksudkan itu disusun dalam ikhtisar dalam laporan keuangan. Laporan keuangan pada dasarnya merupakan hasil repleksi dari sekian banyak transaksi uang terjadi dalam suatu perusahaan. Transaksi - transaksi dan peristiwa yang bersifat financial dicatat, digolongkan, dan diringkaskan dengan cara yang tepat dalam satuan uang dan kemudian diadakan penafsiran untuk berbagai tujuan. Berbagai tindakan tersebut tidak lain merupakan seni pencatatan, penggolongan, peringkasan transaksi dan peristiwa yang bersifat financial dalam cara yang tepat dan dalam bentuk rupiah, dan penafsiran akan hasilnya. Menurut Harahap (2007:105), "laporan keuangan dapat menggambarkan posisi keuangan perusahaan, hasil usaha perusahaan dalam suatu periode, dan arus dana (kas)perusahaan dalam periode tertentu". Menurut Tunggal (2000:79), "laporan keuangan adalah pertanggungjawaban pimpinan suatu perusahaan kepada pemegang saham atau kepada masyarakat umum tentang pengelolaan yang dilaksanakan olehnya dalam suatu masa tertentu, biasanya satu tahun." Menurut Sundjaja (2002:68), "laporan keuangan adalah suatu laporan yang menggambarkan hasil dari proses akuntansi yang digunakan sebagai alat komunikasi antar data keuangan atau aktivitas perusahaan dengan pihak yang berkepentingan dengan data atau aktivitas tersebut". Laporan keuangan merupakan hasil tindakan perbuatan ringkasan data perusahaan. Laporan keuangan ini disusun dan ditafsirkan untuk kepentingan manajemen dan pihak lain yang menaruh perhatian atau mempunyai kepentingan dengan data keuangan perusahaan.

Berdasarkan kutipan diatas, maka dapat disimpulkan bahwa laporan keuangan merupakan hasil dari proses sejumlah transaksi atau peristiwa lain yang diklasifikasikan sesuai sitatu atau fungsinya. Tahap akhir dari proses penggabungan dan pengklasifikasian adalah penyajian laporan keuangan yaitu dalam bentuk laporan neraca dan laporan laba-rugi, sedangkan laporan keuangan lainnya hanya merupakan laporan pelengkap yang bersifat membantu untuk memperoleh penjelasan lebih lanjut.

\section{Tujuan Laporan Keuangan}

Dapat diketahui bahwa setiap laporan keuangan yang dibuat sudah pasti memiliki tujuan tertentu. Dalam praktiknya terdapat beberapa tujuan yang hendak 
dicapai, terutama bagi pemilik usaha dan manajemen perusahaan. Disamping itu, tujuan laporan keuangan disusun guna memenuhi kepentingan berbagai pihak yang berkepentingan terhada perusahaan.

Secara umum laporan keuangan bertujuan untuk memberikan informasi keuangan suatu perusahaan, baik pada saat tertentu maupun pada periode tertentu. Laporan keuangan juga dapat disusun secara mendadak sesuai kebutuhan perusahaan maupun secara berkala. Jelasnya adalah laporan keuangan mampu memberikan informasi keuangan kepada pihak dalam dan luar perusahaan yang memiliki kepentingan terhadap perusahaan. Laporan keuangan juga dapat dijadikan dsebagai alat pertanggungjawaban oleh pihak yang bersangkutan.

\section{Pihak Yang Memerlukan Laporan Keuangan}

Laporan keuangan disusun berdasarkan berbagai tujuan. Tujuan utamanya adalah untuk kepentingan pemilik dan manajemen perusahaan dan memberikan informasi kepada berbagai pihak yang sangat berkepentingan terhadap perusahaan. Hal ini berarti pembuatan dan penyusunan laporan keuangan ditujuka $\mathrm{n}$ untuk memenuhi kepentingan berbagai pihak, baik pihak intern maupun ekstern perusahaan.

Berikut ini penjelasan masing - masing pihak yang berkepentingan terhadap laporan keuangan.

1. Pemilik perusahaan

Dengan menggunakan laporan keuangan, pemilik perusahan dapat menilai sukses tidaknya manajer dalam memimpin perusahaannya dan kesuksesan seorang manajer biasanya diukur dengan laba yang diperoleh perusahaan. Dengan kata lain, laporan keuangan diperlukan oleh pemilik perusahaan untuk menilai hasil-hasil yang telah dicapai dan menilai kemungkinan hasil-hasil yang akan dicapai di masa yang akan datang sehingga bisa menaksir bagian keuntungan yang akan diterima dan perkembangan harga saham yang dimilikinya.

2. Manager atau pimpinan perusahaan

Laporan keuangan digunakan sebagai alat untuk mempertanggungjawabkan kepercayaan yang telah diberikan oleh pemilik perusahaan. Selain itu, laporan keuangan juga digunakan oleh manajemen untuk :
a. mengukur tingkat biaya dari berbagai kegiatan perusahaan,
b. mengukur efisiensi tiap-tiap bagian, proses, atau produksi,
c. mengukur hasil kerja tiap-tiap individu yang telah diserahi wewenang dan tanggung jawab,
d. menentukan perlu tidaknya digunakan kebijaksanaan yang baru untuk mencapai hasil yang lebih baik.

3. Investor

Laporan keuangan digunakan oleh para investor untuk mengetahui jaminan investasinya dan mengetahui kondisi kerja / kondisi keuangan jangka pendek perusahaan tersebut. Selain itu, investor juga menggunakan laporan keuangan dalam rangka penentuan kebijaksanaan penanaman modalnya.

4. Kreditur / banker

Kreditur jangka panjang ini menggunakan laporan keuangan untuk mengukur kemampuan perusahaan dalam membayar utang dan beban- 
beban bunganya dan untuk mengetahui apakah kredit yang akan diberikan itu cukup mendapat jaminan dari perusahaan.

5. Pemerintah

Laporan keuangan digunakan oleh pemerintah untuk menentukan besarnya pajak yang harus ditanggung oleh perusahan serta digunakan sebagai dasar perencanaan pemerintah.

6. Masyarakat

Perusahaan mempengaruhi anggota masyarakat dalam berbagai hal. Perusahaan dapat memberikan kontribusi berarti pada perekonomian nasional, termasuk jumlah orang yang dipekerjakan dan perlindungan pada penanam modal domestik. Laporan keuangan dapat membantu masyarakat dengan menyediakan informasi kecenderungan dan perkembangan terakhir kemakmuran perusahaan serta rangkaian aktivitasnya.

\section{Bentuk-bentuk laporan keuangan}

1. Laporan Posisi Keuangan (Neraca)

Pengertian neraca menurut Sofyan Syafri Harahap, dalam bukunya "Analisis Kritis atas Laporan Keuangan" (2010) adalah suatu laporan yang menggambarkan posisi aktiva, kewajiban dan modal pada saat tertentu.

Menurut Kasmir, dalam bukunya, "Analisis Laporan Keuangan” (2008;), dalam menyusun neraca, perusahaan dapat menggunakan beberapa bentuk sesuai dengan tujuan dan kebutuhannya. Disamping itu, bentuk neraca yang dipilih sesuai dengan aturan dan kelaziman yang berlaku. Artinya penyusunan neraca didasarkan kepada bentuk yang telah distandarisasi, terutama untuk tujuan pihak luar perusahaan.

Dalam praktiknya terdapat beberapa bentuk neraca, yaitu :

a. Bentuk Skontro (Account form), merupakan neraca yang bentuknya seperti huruf "T". Oleh karena itu sering juga disebut T Form. Dalam bentuk ini neraca dibagi kedalam dua posisi, yaitu disebelah kiri berisi aktiva dan sebelah kanan yang berisi kewajiban dan modal.

b. Bentuk Vertikal (Report form). Dalam bentuk laporan isi neraca disusun mulai dari atas terus kebawah, yaitu mulai dari aktiva lancar seperti kas, bank, efek, ialah komponen aktiva tetap,komponen aktiva lainnya, komponen kewajiban lancar, komponen utang jangka panjang dan terakhir adalah komponen modal (ekuitas).

Neraca terdiri dari tiga bagian utama, yaitu :

1) Aktiva

Pengertian aktiva menurut Munawir, Akuntan dalam bukunya Analisa Laporan Keuangan (2007), adalah aktiva yang tidak terbatas pada kekayaan perusahaan yang belum dialokasikan (deffered charges) atau biaya yang masih harus dialokasikan pada penghasilan yang akan datang, serta aktiva yang tidak berwujud lainnya (intangible assets).

Aktiva diklasifikasikan menjadi dua bagian yaitu :

a) Aktiva Lancar

Adalah uang kas dan aktiva lainnya yang dapat diharapkan untuk dicairkan atau ditukarkan menjadi uang tunai, dijual atau dikonsumer dalam periode berikutnya (paling lama satu tahun 
atau dalam perputaran kegiatan perusahaan yang normal). Berikut ini terdapat lima unsur pokok dari aktiva lancar, yaitu:

Kas yang digunakan untuk membiayai operasional perusahaan. Dan pengertian kas adalah check yang diterima dari para pelanggan dan simpanan perusahaan di bank dalam bentuk giro atau demand deposit, yaitu simpanan di bank yang dapat diambil kembali (dengan menggunakan check atau bilyet) setiap saat diperlukan oleh perusahaan.

Investasi jangka pendek (surat-surat berharga) yang sifatnya sementara (jangka pendek) dengan maksud memanfaatkan uang kas untuk sementara belum dibutuhkan dalam operasi.

Piutang penghasilan (tagihan) atau penghasilan yang harus diterima adalah salah satu jenis transaksi akuntansi yang mengurusi penagihan konsumen yang berhutang pada seseorang, suatu perusahaan atau suatu organisasi untuk barang dan layanan yang telah diberikan pada konsumen tersebut.

Persediaan adalah semua barang-barang yang diperdagangkan yang sampai tanggal neraca masih di gudang atau masih belum laku terjual.

biaya dibayar dimuka adalah pengeluaran untuk memperoleh jasa atau prestasi dari pihak lain.

b) Aktiva Tetap

Adalah aktiva yang mempunyai umur kegunaan relatif permanen atau jangka panjang (mempunyai unsur ekonomis lebih dari satu tahun atau tidak akan habis dalam satu kali perputaran operasi perusahaan seperti : tanah, bangunan, mesin, inventaris, kendaraan dan kelengkapan lainnya.

c) Aktiva Lain-Lain adalah aktiva perusahaan yang tidak dapat atau belum dapat dimasukkan dalam klasifikasi-klasifikasi sebelumnya. Seperti : gedung dalam proses, tanah dalam penyelesaian.

2) Hutang

Menurut Munawir, dalam bukunya "Analisa Laporan Keuangan" (2007), hutang adalah semua kewajiban keuangan perusahaan kepada pihak lain yang belum terpenuhi, dimana hutang ini merupakan sumber dana atau modal perusahaan yang berasal dari kreditur. Hutang atau kewajiban perusahaan dapat dibedakan menjadi dua macam, yaitu :

a) Hutang Lancar atau hutang jangka pendek adalah kewajiban keuangan perusahaan yang pelunasannya atau pembayaran akan dilakukan dalam jangka pendek (satu tahun sejak tanggal neraca) dengan menggunakan aktiva lancar yang dimiliki oleh perusahaan.Hutang lancar meliputi : hutang dagang, hutang wesel, hutang pajak, biaya yang masih harus dibayar, hutang jangka panjang yang segera jatuh tempo, penghasilan yang diterima dimuka.

b) Hutang Jangka Panjang adalah kewajiban keuangan yang jangka waktu pembayarannnya (jatuh temponya) masih jangka panjang 
(lebih dari satu tahun sejak tanggal neraca), yang meliputi : hutang obligasi, hutang hipotik, pinjaman jangka panjang lainnya.

c) Modal

Menurut Munawir, dalam bukunya, "Analisa Laporan Keuangan" (2007:) modal adalah merupakan hak atau bagian yang dimiliki oleh pemilik perusahaan yang ditunjukkan dalam pos modal (modal saham), laba ditahan. Atau kelebihan nilai aktiva yang dimiliki oleh perusahaan terhadap seluruh hutanghutangnya.

\section{Laporan Rugi Laba (Income Statement)}

Menurut Kasmir, dalam bukunya, “Analisa Laporan Keuangan” (2012;), Laporan rugi laba merupakan laporan yang menunjukkan kondisi usaha dalam suatu periode tertentu yang tergambar dari jumlah pendapatan yang diterima dan biaya yang telah dikeluarkan sehingga dapat diketahui apakah perusahaan dalam keadaan laba atau rugi. Bentuk Laporan Rugi Laba

Menurut Kasmir, dalam bukunya, "Analisa Laporan Keuangan" (2012;), bentuk dari laporan rugi / laba yang bisa digunakan adalah sebagai berikut"

a. Bentuk Tunggal atau single step, yaitu dengan menggabungkan semua penghasilan, baik pokok (operasional) maupun diluar pokok (non operasional) dijadikan satu, kemudian jumlah biaya pokok dan diluar pokok juga dijadikan satu. Dengan demikian, faktor pengurangnya adalah jumlah seluruh penghasilan dengan jumlah seluruh biaya. Artinya dalam bentuk ini laporan laba rugi disusun tanpa membedakan pendapatan dan biaya usaha dan diluar usaha lain.

b. Bentuk Majemuk atau Multiple Step, merupakan pemisahan antara komponen usaha pokok (operasional) dengan diluar pokok (non operasional). Artinya terlebih dahulu dikurangi antara penghasilan pokok dengan biaya pokok, kemudian baru ditambah dengan hasil pengurangan penghasilan dan biaya diluar pokok.

3. Laporan Perubahan Modal

Laporan perubahan modal adalah ikhtisar tentang perubahan modal yang terjadi selama jangka waktu tertentu. Hal-hal yang menyebabkan perubahan modal adalah adanya setoran tambahan dari pemilik, adanya laba usaha, dan adanya kerugian atau pengambilan untuk keperluan pribadi (prive).

4. Laporan Aliran Kas

Adalah laporan keuangan yang memperlihatkan penerimaan kas dan pengeluaran kas suatu perusahaan selama suatu periode waktu. Tujuan pokok aliran kas adalah untuk memberikan informasi mengenai penerimaan dan pembayaran kas perusahaan selama periode tertentu.

\section{Pengertian Analisis Rasio Keuangan}

Syahyunan (2004:81) menyatakan bahwa : "Analisis Rasio Keuangan merupakan analisis yang paling popular untuk mengidentifikasian kondisi keuangan perusahaan dan kinerja keuangan perusahaan”. Rasio keuangan merupakan suatu cara membuat perbandingan data keuangan perusahaan, sehingga menjadi dasar untuk menjawab beberapa pertanyaan penting keadaan keuangan suatu perusahaan. Mempelajari hubungan antara berbagai pos - pos laporan keuangan itu. Hubungan antara pos yang satu dengan yang lain 
dinyatakan dengan angka yang dinamakan rasio.

Djarwanto (2001:123), yang dimaksud dengan rasio dalam analisis laporan keuangan adalah : "Suatu angka yang menunjukkan hubungan antara suatu unsur dengan unsur lainnya dalam laporan keuangan. Hubungan antara unsur - unsur laporan keuangan tersebut dinyatakan dalam bentuk matematis yang sederhana". Bambang (2001:253) "Rasio hanyalah alat yang dinyatakan dalam arithmetical term yang dapat digunakan untuk menjelaskan hubunngan antara dua macam data financial".

Analisis ini merupakan suatu analisis yang dilakukan untuk mengetahui tingkat kemampuan perusahaan untuk memperoleh laba yang maksimal dan juga dalam mengelola perusahaan semaksimal mungkin. Hasil analisis nantinya akan diketahui tingkat kemampuan perusahaan yang ditujukan dalam bentuk angka atau persentase. Berdasarkan pengertian analisis rasio diatas, maka dapat disimpulkan bahwa dengan mengadakan analisis rasio terhadap laporan keuangan dalam suatu perusahaan adalah sangat penting bagi pihak yang berkepentingan terhadap perusahaan yang bersangkutan walaupun kepentingan mereka masing masing berbeda.

Menurut Syahyunan ( 2004:82) untuk mengidentifikasikan kondisi keuangan dapat dibandingkan dengan dua cara yaitu perbandingan antar waktu dan perbandingan antar perusahaan.

1. Perbandingan Antar Waktu (Trend Analysis)

Perbandingan antar waktu adalah rasio keuangan yang sekarang dibandingkan dengan perkiraan rasio keuangan tahun yang akan datang dalam perusahaan yang sama suatu perusahaan. Perbandingan itu dapat dilihat arah perubahan apakah naik atau sebaliknya turun.

2. Perbandingan Antar Perusahaan

Perbandingan antara perusahaan ini dapat dilihat apakah rasio keuangan perusahaan relative sama atau berbeda dengan perusahaan lainnya atau rata - rata industri.

\section{Jenis - Jenis Analisis Rasio Keuangan}

Ada beberapa analisis rasio keuangan yang dilakukan oleh pihak manajemen perusahaan sehubungan dengan usaha untuk mengetahui tingkat kemampuan perusahaan dalam suatu perekonomian. Bambang (2001:245) menggolongkan rasio tersebut terdiri dari Rasio neraca, Rasio laporan laba rugi, dan Rasio antar laporan.

a. Rasio Neraca (Balance Sheet Ratio)

Rasio neraca yaitu rasio yang disusun dari data yang berasal dari neraca misalnya: rasio lancar (current ratio), rasio tunai (quick ratio), rasio modal sendiri dengan total aktiva, rasio aktiva tetap dengan hutang jangka panjang dan sebagainya.

b. Rasio Laporan Laba Rugi (Income Statment Ratio)

Rasio laporan laba rugi yaitu rasio yang disusun dari data yang berasal dari laporan laba rugi, misalnya rasio laba bruto dengan penjualan netto, rasio laba usaha dengan penjualan laba netto, operating ratio, dan lain sebagainya.

c. Rasio Antar Laporan (Inter Statment Ratio)

Rasio antar laporan yaitu rasio yang disusun dari data yang berasal dari neraca dan laporan laba rugi, misalnya: rasio penjualan netto dengan 
aktiva usaha, rasio penjualan kredit dengan piutang rata - rata, rasio harga pokok penjualan dengan persediaan rata - rata dan sebagainya.

\section{Pengertian Profitabilitas}

Profitabilitas merupakan kemampuan suatu perusahaan untuk mendapatkan laba (keuntungan) dalam suatu periode tertentu. Pengertian yang sama disampaikan oleh Husnan (2001) bahwa Profitabilitas adalah kemampuan suatu perusahaan dalam menghasilkan keuntungan (profit) pada tingkat penjualan, aset, dan modal saham tertentu. Sedangkan Menurut Michelle \& Megawati (2005) Profitabilitas merupakan kemampuan perusahaan menghasilkan laba (profit) yang akan menjadi dasar pembagian dividen perusahaan.

Prolitabilitas menggambarkan kemampuan badan usaha untuk menghasilkan laba dengan menggunakan seluruh modal yang dimiliki. Hal ini sesuai dengan pernyataan Shapiro (1991:731) "Profitability ratios measure managements objectiveness as indicated by return on sales, assets and owners equity."

Profitabilitas suatu perusahaan akan mempengaruhi kebijakan para investor atas investasi yag dilakukan. Kemampuan peurusahaan untuk menghasilkan laba akan dapat menarik para investor untuk menanamkan dananya guna memperluas usahanya, sebaliknya tingkat profitabilitas yang rendah akan menyebabkan para investor menarik dananya. Sedangkan bagi perusahaan itu sendiri profitabilitas dapat digunakan sebagai evaluasi atas efektivitas pengelolaan badan usaha tersebut.

Profitabilitas perusahaan merupakan salah satu dasar penilaian kondisi suatu perusahaan, untuk itu dibutuhkan suatu alat analisis untuk bisa menilainya. Alat analisis yang dimaksud adalah rasio-rasio keuangan. Ratio profitabilitas mengukur efektifitas manajemen berdasarkan hasil pengembalian yang diperoleh dari penjualan dan investasi.

Profitabilitas juga mempunyai arti penting dalam usaha mempertahankan kelangsungan hidupnya dalam jangka panjang, karena profitabilitas menunjukkan apakah badan usaha tersebut mempunyai prospek yang baik di masa yang akan datang. Dengan demikian setiap badan usaha akan selalu berusaha meningkatkan profitabilitasnya, karena semakin tinggi tingkat profitabilitas suatu badan usaha maka kelangsungan hidup badan usaha tersebut akan lebih terjamin.

Penilaian profitabilitas adalah proses untuk menentukan seberapa baik aktivitas-aktivitas bisnis dilaksanakan untuk mencapai tujuan strategis, mengeliminasi pemborosan-pemborosan dan menyajikan informasi tepat waktu untuk melaksanakan penyempurnaan secara berkesinambungan (Supriyono. 1999).

Ada beberapa pengukuran kinerja terhadap profitabilitas perusahaan dimana masing- masing pengukuran dihubungkan dengan volume penjualan, total aktiva dan modal sendiri.

Secara keseluruhan ketiga pengukuran ini akan memungkinkan seorang analis untuk mengevaluasi tingkat earning dalam hubungannya dengan volume penjualan jumlah aktiva dan investasi tertentu dari pemilik perusahaan.

Profitabilitas keuangan perusahaan dideskripsikan dalam bentuk laporan laba-rugi yang merupakan bagian dari laporan keuangan korporasi, yang dapat digunakan oleh semua pihak yang berkepentingan untuk membuat keputusan 
ekonomi. Berdasarkan financial report yang diterbitkan perusahaan, selanjutnya dapat digali informasi mengenai posisi keuangan perusahaan, struktur permodalan, aliran kas, kinerja keuangan dan informasi lain yang mempunyai relevansi dengan laporan keuangan perusahaan.

Profitabilitas keuangan perusahaan sudah tentu merupakan kinerja perusahaan yang ditinjau dari kondisi keuangan perusahaan. Profitabilitas keuangan perusahaan tercermin dari laporan keuangannya, oleh sebab itu untuk mengukur profitabilitas keuangan perusahaan diperlukan analisis terhadap laporan keuangannya.

Menurut pendapat Shapiro (1991) yang menunjukkan bahwa profitabilitas sangat cocok untuk mengukur efektivitas manajemen dan pengevaluasian kinerja manajemen dalam menjalankan bisnis dan produktivitasnya dalam mengelola aset-aset perusahaan secara keseluruhan seperti yang nampak pada pengembalian yang dihasilkan oleh penjualan dan investasi, serta untuk mengevaluasi kinerja ekonomi dari bisnis. Secara umum profitabilitas merupakan pengukuran dari keseluruhan produktivitas dan kinerja perusahaan yang pada akhirnya akan menunjukkan efisiensi dan produktivitas perusahaan tersebut.

Dwi Prastowo (2008) menyatakan bahwa informasi kinerja perusahaan, terutama profitabilitas diperlukan untuk menilai perubahan potensial sumber daya ekonomi yang mungkin dikendalikan di masa depan, sehingga dapat memprediksi kapasitas perusahaan dalam menghasilkan kas (dan setara kas) serta untuk merumuskan efektifitas perusahaan dalam memanfaatkan tambahan sumber daya.

Rasio profitabilitas merupakan rasio untuk menilai kemampuan perusahaan dan mencari keuntungan. Rasio ini juga memberikan ukuran tingkat efektifitas manajemen suatu perusahaan. Hal ini ditunjukkan oleh laba yang dihasilkan dari penjualan dan pendapatan investasi. Intinya adalah penggunaan rasio ini menunjukkkan efisiensi perusahaan.

Penggunaan rasio profitabilitas dapat dilakukan dengan menggunakan perbandingan antara berbagai komponen yang ada dilaporan keuangan neraca dan laporan laba rugi. Pengukuran dapat dilakukan untuk beberapa periode operasi. Tujuannya adalah agar terlihat perkembangan perusahaan dalam rentang waktu tertentu, baik penurunan atau kenaikan, sekaligus mencari penyebab perubahan tersebut.

Hasil pengukuran tersebut dapat dijadikan alat evaluasi kinerja manajemen selama ini, apakah mereka telah bekerja secara efektif atau tidak. Jika berhasil mencapai target yang telah ditentukan mereka dikatakan telah berhasil mencapai target untuk periode atau beberapa periode, sebaliknya jika gagal atau tidak berhasil mencapai target yang telah ditentukan, ini akan menjadi pelajaran bagi manajemen untuk periode ke depan. Kegagalan ini harus diselidiki dimana letak kesalahan dan kelemahannya sehingga kejadian tersebut tidak terulang. Kegagalan atau keberhasilan dapat dijadikan sebagai bahan acuan untuk perencanaan laba ke depan, sekaligus kemungkinan untuk menggantikan manajemen yang baru terutama setelah manajemen lama mengalami kegagalan. Rasio Profitabilitas ini sering disebut sebagai salah satu alat ukur kinerja manajemen.

Sama halnya dengan rasio-rasio lain, rasio profitabilitas juga 
memiliki tujuan dan manfaat, tidak hanya bagi pihak pemilik usaha atau manajemen saja, tetapi juga bagi pihak diluar perusahaan, terutama pihak-pihak yang memiliki hubungan atau kepentingan dengan perusahaan.

Tujuan penggunaan rasio profitabilitas bagi perusahaan, maupun bagi pihak luar perusahaan, yaitu;

1. Untuk mengukur atau menghitung laba yang diperoleh perusahaan dalam satu periode tertentu.

2. Untuk menilai posisi laba perusahaan tahun sebelumnya dengan tahun sekarang.

3. Untuk menilai perkembangan laba dari waktu ke waktu.

4. Untuk menilai besarnya laba bersih sesudah pajak dengan modal sendiri.

5. Untuk mengukur produktivitas seluruh dana perusahaan yang digunakan baik modal pinjaman maupun modal sendiri.

6. Untuk mengukur produktivitas dari seluruh dana perusahaan yang digunakan baik modal sendiri.

7. Dan tujuan lainnya.

Sementara itu, manfaat yang diperoleh adalah untuk mengetahui besarnya tingkat laba yang diperoleh perusahaan dalam satu periode.

a. Mengetahui posisi laba perusahaan tahun sebelumnya dengan tahun sekarang.

b. Mengetahui perkembangan laba dari waktu ke waktu;

c. Mengetahui besarnya laba bersih sesudah pajak dengan modal sendiri;

d. Mengetahui produktivitas dari seluruh dana perusahaan yang digunakan baik modal pinjaman maupun modal sendiri

e. Manfaat lainnya.

\section{Jenis-jenis Rasio Profitabilitas}

Sesuai dengan tujuan yang hendak dicapai, terdapat beberapa jenis rasio profitabilitas yang dapat digunakan. Masing-masing jenis rasio profitabilitas digunakan untuk menilai serta mengukur posisi keuangan perusahaan dalam suatu periode tertentu atau untuk beberapa periode.

Penggunaan seluruh atau sebagian rasio profitabilitas tergantung dari kebijakan manajemen. Jelasnya, semakin lengkap jenis rasio yang digunakan semakin sempurna hasil yang akan dicapai. Artinya pengetahuan tentang kondisi dan posisi profitabilitas perusahaan dapat diketahui secara sempurna.

a. Net Profit Margin

Net profit margin merupakan rasio perbandingan antara laba bersih setelah pajak dengan penjualan (Warsosno,2003:37). Besarnya perhitungan margin laba bersih menunjukkan seberapa besar laba setelah pajak yang diperoleh perusahaan untuk tingkat penjualan tertentu. Rasio ini menunjukkan keuntungan bersih per rupiah penjualan. net profit margin $3 \%$ berarti bahwa setiap Rp 1 penjualan menghasilkan keuntungan bersih sebesar Rp 0,03.

Semakin besar rasio ini semakin baik karena dianggap kemampuan perusahaan dalam mendapatkan laba cukup tinggi Net Margin ratio menurut Sutojo (2004:56) merupakan perbandingan antara laba bersih dengan penjualan. Artinya berapa persen keuntungan bersih yang diperoleh oleh perusahaan selama periode tertentu (tahun buku) dari setiap rupiah penjualan. 


$$
N P M=\frac{\text { Laba bersih setelah pajak }}{\text { Penjualan bersih }}
$$

b. ROI ( Return On Invesment )

ROI ( Return On Invesment ) mencerminkan kemampuan manajemen dalam mengatur aktiva-aktivanya seoptimal mungkin sehingga dicapai laba bersih yang diinginkan. Rasio ini mengukur kemampuan perusahaan dengan jumlah aktiva yang digunakan dalam operasi perusahaan untuk menghasilkan keuntungan. Rasio ini menunjukkan produktivitas dari seluruh dana perusahaan baik modal pinjaman maupun modal sendiri. Semakin kecil / rendah rasio ini semakin tidak baik, demikian juga sebaliknya. Rumus dari ROI ( Return On Invesment ) adalah sebagai berikut :

$$
R O I=\frac{\text { Laba bersih setelah pajak }}{\text { Total aktiva }}
$$

c. ROE ( Return On Equity )

ROE ( Return On Equity ) adalah rasio yang menunjukkan kemampuan perusahaan dalam menghasilkan laba bersih dengan menggunakan modal sendiri dan menghasilkan laba bersih yang tersedia bagi pemilik atau investor. ROE sangat bergantung pada besar kecilnya perusahaan, misalnya untuk perusahaan kecil tentu memiliki modal yang relative kecil, sehingga ROE yang dihasilkanpun kecil , begitu pula sebaliknya untuk perusahaan besar. ROE ( Return On Equity ) membandingkan laba bersih setelah pajak dengan ekuitas yang telah diinvestasikan pemegang saham perusahaan (Van Horne dan Wachowicz, 2005:225). Rasio ini menunjukkan daya untuk menghasilkan laba atas investasi berdasarkan nilai buku para pemegang saham, dan sering kali digunakan dalam membandingkan dua atau lebih perusahaan atas peluang investasi yang baik dan manajemen biaya yang efektif. Menurut Tandelilin (2002:269),"'ROE(Return On Owners Equity ) mereflesikan seberapa banyak perusahaan telah memperoleh hasil atas dana yang telah diinvestasikan oleh pemegang saham (baik secara langsung atau dengan laba yang telah ditahan)". ROE sangat menarik bagi pemegang saham maupun calon pemegang saham, dan juga bagi manajemen Karen arsio tersebut merupakan ukuran atau indicator penting dari shareholders value cration, artinya semakin tinggi rasio ROE, semakin tinggi pula nilai perusahaan, hal ini tentunya merupakan daya tarik bagi investor untuk menanamkan modalnya diperusahaan tersebut. Brigham, Enrhardt (2005:225), "ROE ( Return On Equity ) mengukur daya perusahaan untuk menghasilkan laba pada investasi nilai buku pemegang saham". Menurut Gibson ( 2001:294)," Return On Equity measures the return to the common stockholders the residual owner". Pengembalian laba atas ekuitas yang terdiri dari saham biasa (Return On Common equity) merupakan alat ukur terhadap pengembalian laba kepada pemegang saham biasa. Rasio ini menggambarkan berapa persen diperoleh laba bersih bila diukur dari modal sendiri. Semakin tinggi rasio ini semakin baik karena berarti posisi pemilik perusahaan semakin kuat, demikian juga sebaliknya. 
Rumus ROE ( Return On Equity ) adalah sebagai berikut :

$$
R O E=\frac{\text { Laba bersih setelah pajak }}{\text { Modal sendiri }}
$$

Tabel 2

Penilaian Ratio Menurut BEI

\begin{tabular}{|l|c|c|c|}
\hline \multicolumn{1}{|c|}{ Ratio provitabilitas } & Angka & Persentase & Kategori \\
\hline Net profit margin & $>0,2$ & $>20 \%$ & Baik \\
Return on investment & $>0,4$ & $>40 \%$ & Baik \\
Return on equity & $>0,3$ & $>30 \%$ & Baik \\
\hline
\end{tabular}

Sumber : BEI

\section{METODE PENELITIAN}

Dalam pengumpulan data dan bahan untuk melakukan penelitian ini digunakan metode pengumpulan data sebagai berikut :

1. Metode Pengumpulan Data

a. Penelitian Lapangan (Field Research)

yaitu suatu metode penelitian dengan cara mendatangi langsung ke perusahaan yang menjadi objek kajian. Teknik pengumpulan data yang dilakukan yaitu wawancara dan observasi.

b. Studi Pustaka (Library Research)

yaitu penelitian yang dilakukan ke perpustakaan beberapa buku-buku ilmiah dan tulisan-tulisan yang berhubungan dengan pembahasan yang dilakukan.

2. Metode Analisa Data

Dalam menganalisa data, penulis menggunakan analisis data kuantitatif sebagai metode penelitian yang menjelaskan secara deskriptif mengenai analisis rasio terhadap laporan keuangan PT. Bank perkreditan rakyat Pagaruyung untuk periode 2012 dan 2013. Metode analisis ditinjau dari dua praktek yang perlu diterapkan, sehingga dapat diketahui sejauh mana pelaksanaannya. Apakah perbedaan yang timbul menyangkut prinsip dasar konsep itu sendiri, pertanyaan itu akan terjawab selanjutnya dari hasil analisa itu digunakan sebagai dasar pengambilan kesimpulan dan saran.

\section{HASIL DAN PEMBAHASAN}

Perusahaan dapat menentukan apakah kinerja keuangannya baik atau tidak. Penilaian ini dilakukan dengan membandingkan rasio keuangan yang diperoleh dengan standar rasio keuangan yang ada. Pada umumnya, kinerja keuangan perusahaan dapat dikategorikan baik jika besarnya rasio keuangan perusahaan bernilai sama dengan atau di atas standar rasio keuangan.

Dari hasil perhitungan yang telah penulis lakukan terhadap nilai rasio profitabilitas terhadap laporan keuangan CV. DELTA AGUNG PRATAMA , diperoleh nilai rasio sebagaimana yang terlihat pada tabel 3. dibawah ini: 


\section{Net Profit Margin}

$$
\mathrm{NPM}=\frac{\text { Laba bersih setelah pajak }}{\text { Penjualan bersih }}
$$

Net Profit Margin dari tahun 2013 sampai tahun 2015 perhitungannya sebagai berikut:

$$
\text { Tahun } 2013 \mathrm{NPM}=\frac{79 \cdot 308 \cdot 300}{494 \cdot 790.000}=0,16
$$

Margin laba yang diperoleh perusahaan pada tahun 2013 adalah 0,16 Ini menunjukkan bahwa kemampuan perusahaan dalam menghasilkan laba bersih dari aktivitas penjualan hanya 0,16 .

$$
\text { Tahun } 2014 \mathrm{NPM}=\frac{52 \cdot 970.340}{456 \cdot 264 \cdot 000}=0,11
$$

Margin laba yang diperoleh perusahaan pada tahun 2014 adalah 0,11 Ini menunjukkan bahwa kemampuan perusahaan dalam menghasilkan laba bersih dari aktivitas penjualan hanya 0,11

$$
\text { Tahun } 2015 \text { NPM }=\frac{65 \cdot 189 \cdot 100}{481 \cdot 520 \cdot 000}=0,13
$$

Margin laba yang diperoleh perusahaan pada tahun 2015 adalah 0,13. Ini menunjukkan bahwa kemampuan perusahaan dalam menghasilkan laba bersih dari aktivitas penjualan hanya 0,13 .

Tabel 3

Perhitungan Net Profit Margin

Tahun $2013-2015$

( Dalam Rp )

\begin{tabular}{cccr}
\hline Tahun & $\begin{array}{c}\text { Laba Bersih } \\
(1)\end{array}$ & $\begin{array}{c}\text { Penjualan Bersih } \\
(2)\end{array}$ & $\begin{array}{c}\text { NPM } \\
(1: 2)\end{array}$ \\
\hline 2013 & 79.308 .300 & 494.790 .000 & 0,16 \\
2014 & 52.970 .340 & 456.264 .000 & 0,11 \\
2015 & 65.189 .100 & 481.520 .000 & 0,13 \\
\hline
\end{tabular}

Sumber : CV. Delta Agung Pratama, data diolah

Berdasarkan tabel diatas dapat dilihat bahwa rasio margin laba perusahaan CV.Delta Agung Pratama mengalami fluktuasi. Dimana margin laba pada tahun 2013 adalah sebesar 0,16 Pada tahun 2014 mengalami penurunan sebesar 0,05 sehingga margin perusahaan menjadi 0,11. Pada tahun 2015 mengalami kenaikan sebesar 0,02 sehingga margin laba perusahaan menjadi 0,13 . Jika dibandingkan dengan rasio rata-rata industri perusahaan sudah tergolong kurang baik. Karena margin laba perusahaan berada dibawah rata-rata industri. Besar rata-rata industri adalah 0,2 . Semakin besar rasio yang diperoleh perusahaan maka semakin baik, bila semakin kecil rasio yang diperoleh perusahaan maka 
semakin buruk karena perusahaan dianggap tidak mampu menciptakan laba yang cukup tinggi dari aktivitas penjualannya .

\section{Return On Investment}

Rasio ini merupakan perbandingan antara laba bersih dengan total aktiva. Rasio ini mengukur kemampuan modal yang diinvestasikan dalam menghasilkan laba/keuntungan dengan rumus:

$$
R O I=\frac{\text { Laba bersih setelah pajak }}{\text { Total aktiva }}
$$

Return On Investment dari tahun 2013 sampai tahun 2015 perhitungannya sebagai berikut:

$$
\text { Tahun 2013ROI }=\frac{79.308 .300}{273.464 .333}=0,29
$$

Hasil pengembalian yang diperoleh CV.Delta Agung Pratama pada tahun 2013 adalah sebesar 0,29 Ini menunjukkan kemampuan perusahaan dalam mengahasilkan laba bersih dari aktiva adalah sebesar 0,29.

$$
\text { Tahun } 2014 \text { ROI }=\frac{52.970 .340}{266.134 .673}=0,19
$$

Hasil pengembalian yang diperoleh CV.Delta Agung Pratama pada tahun 2014 adalah sebesar 0,19 Ini menunjukkan kemampuan perusahaan dalam mengahasilkan laba bersih dari aktiva adalah sebesar 0,19 .

$$
\text { Tahun } 2015 \text { ROI }=\frac{65 \cdot 189 \cdot 100}{275 \cdot 623 \cdot 773}=0,23
$$

Hasil pengembalian yang diperoleh CV.Delta Agung Pratama pada tahun 2015 adalah sebesar 0,23 Ini menunjukkan kemampuan perusahaan dalam mengahasilkan laba bersih dari aktiva adalah sebesar 0,23.

Tabel 4

Perhitungan Return On Investment

Tahun $2013-2015$

( Dalam Rp )

\begin{tabular}{llcc}
\hline Tahun & Laba Bersih & Total Aktiva & ROI \\
& $(1)$ & $(2)$ & $(1: 2)$ \\
\hline 2013 & 79.308 .300 & 273.464 .333 & 0,29 \\
2014 & 52.970 .340 & 266.134 .673 & 0,19 \\
2015 & 65.189 .100 & 275.623 .773 & 0,23 \\
\hline
\end{tabular}

Sumber : CV. Delta Agung Pratama, data diolah

Dari tabel diatas dapat dilihat bahwa ROI CV.Delta Agung Pratama setiap tahunnya masih mengalami fluktuasi. Pada tahun 2013 ROI perusahaan sebesar 0,29. Pada tahun 2014 ROI perusahaan menurun sebesar 0,10 sehingga ROI perusahaan menjadi 0,19 Pada tahun 2015 ROI perusahaan mulai naik sebesar 0,04 sehingga ROI perusahaan menjadi 0,23. Jika dibandingkan dengan 
rata-rata industri perusahaan tergolong kurang baik, karena sudah berada dibawah rasio rata-rata industri. Besarnya rasio rata-rata industri adalah 0,3 . Jadi semakin tinggi tingkat perputaran aktiva maka akan semakin tinggi pula laba yang akan diperoleh oleh perusahaan, sebaliknya Jadi semakin rendah perputaran aktiva maka akan semakin rendah pula laba yang akan diperoleh oleh perusahaan

\section{Return On Equity}

Rasio ini menunjukkan berapa besar laba bersih bila diukur dari modal saham tertentu. Rasio ini merupakan ukuran profitabilitas dari sudut pandang pemegang saham. Rasio ini dapat diukur dengan rumus:

$$
R O E=\frac{\text { Laba bersih setelah pajak }}{\text { Modal Sendiri }}
$$

Return On Equity dari tahun 2013 sampai tahun 2015 perhitungannya sebagai berikut:

$$
\text { Tahun } 2013 \mathrm{ROE}=\frac{79.308 .300}{4.788 .033}=16,56
$$

Besarnya ROE yang diperoleh oleh CV.Delta Agung Pratama pada tahun 2013 adalah 16,56. Ini berarti bahwa kemampuan perusahaan dalam menghasilkan laba bersih jika diukur dari modal adalah sebesar 16,56

$$
\text { Tahun } 2014 \text { ROE }=\frac{52.970 .340}{75.596 .333}=0,7
$$

Besarnya ROE yang diperoleh oleh CV.Delta Agung Pratama pada tahun 2014 adalah 0,7 Ini berarti bahwa kemampuan perusahaan dalam menghasilkan laba bersih jika diukur dari modal adalah sebesar 0,7.

$$
\text { Tahun } 2015 \quad \mathrm{ROE}=\frac{65 \cdot 189 \cdot 100}{116 \cdot 380 \cdot 673}=0,56
$$

Besarnya ROE yang diperoleh oleh CV.Delta Agung Pratama pada tahun 2015 adalah 0,56 Ini berarti bahwa kemampuan perusahaan dalam menghasilkan laba bersih jika diukur dari modal adalah sebesar 0,56

Tabel 5

Perhitungan Return On Equity

Tahun $2013-2015$

( Dalam Rp )

\begin{tabular}{cccc}
\hline Tahun & $\begin{array}{c}\text { Laba Bersih } \\
(1)\end{array}$ & $\begin{array}{c}\text { Modal Sendiri } \\
(2)\end{array}$ & $\begin{array}{c}\text { ROE } \\
(1: 2)\end{array}$ \\
\hline 2013 & 79.308 .300 & 4.788 .033 & 16,56 \\
2014 & 52.970 .340 & 75.596 .333 & 0,7 \\
2015 & 65.189 .100 & 116.380 .673 & 0,56 \\
\hline
\end{tabular}

Sumber : CV. Delta Agung Pratama, data diolah

Pada tabel 3.13 terlihat bahwa ROE perusahaan tahun 2013 menunjukkan angka sebesar 16,56 yang berarti bahwa tingkat penghasilan dari modal yang diinvestasikan menghasilkan laba sebesar 16,56 
Pada tahun 2014, rasio ini mengalami penurunan yang cukup besar yaitu sebesar 15,86 menjadi 0,7 yang berarti tingkat penghasilan dari modal yang diinvestasikan menghasilkan laba sebesar 0,7 Penurunan ini disebabkan atas berkurangnya laba bersih perusahaan sebesar Rp. 38.526 .000

Pada tahun 2015, rasio ini kembali mengalami penurunan yaitu sebesar 0,14 menjadi 0,56 yang berarti tingkat penghasilan dari modal yang diivestasikan menghasilkan laba sebesar 0,56 Penurunan nilai rasio ini disebabkan atas kenaikan modal sendiri yang cukup besar dibandingkan kenaikan laba bersih.

Dari perhitungan ROE perusahaan yang terjadi dari tahun 2013 sampai tahun 2015, dapat terlihat bahwa ROE perusahaan terus mengalami penurunan setiap tahun nya. Penurunan nilai ROE yang terlihat jelas yaitu pada tahun 2014 sebanyak 15,85 Tetapi kinerja perusahaan masih dapat dikatakan baik karena perusahaan tidak mengalami kerugian atas hal itu.

\section{SIMPULAN}

Berdasarkan analisis laporan keuangan dengan menggunakan rasio profitabilitas dalam menilai kemampuan perusahaan untuk memperoleh laba pada laporan keuangan pada Cv. Delta Agung Pratama tahun 2013 sampai dengan tahun 2015, dapat ditarik kesimpuln sebagai berikut :

1. Tingkat perhitungan dengan menggunakan Net profit margin merupakan rasio perbandingan antara laba bersih setelah pajak dengan penjualan Besarnya perhitungan margin laba bersih menunjukkan seberapa besar laba setelah pajak yang diperoleh perusahaan untuk tingkat penjualan tertentu dalam laporan keuangan CV.Delta Agung Pratama Dimana margin laba pada tahun 2013 adalah sebesar 0,16 Pada tahun 2014 mengalami penurunan sebesar 0,05 sehingga margin perusahaan menjadi 0,11. Pada tahun 2015 mengalami kenaikan sebesar 0,02 sehingga margin laba perusahaan menjadi 0,13 . Jika dibandingkan dengan rasio rata-rata industri perusahaan sudah tergolong kurang baik. Karena margin laba perusahaan berada dibawah rata-rata industri. Besar rata-rata industri adalah 0,2. Semakin besar rasio yang diperoleh perusahaan maka semakin baik, bila semakin kecil rasio yang diperoleh perusahaan maka semakin buruk karena perusahaan dianggap tidak mampu menciptakan laba yang cukup tinggi dari aktivitas penjualannya.

2. Tingkat perhitungan dengan menggunakan ROI ( Return On Invesment ) mencerminkan kemampuan manajemen dalam mengatur aktiva-aktivanya seoptimal mungkin sehingga dicapai laba bersih yang diinginkan dalam laporan keuangan CV.Delta Agung Pratama Pada tahun 2013 ROI perusahaan sebesar 0,29. Pada tahun 2010 ROI perusahaan menurun sebesar 0,10 sehingga ROI perusahaan menjadi 0,19 Pada tahun 2015 ROI perusahaan mulai naik sebesar 0,04 sehingga ROI perusahaan menjadi 0,23. Jika dibandingkan dengan rata-rata industri perusahaan tergolong kurang baik, karena sudah berada dibawah rasio rata-rata industri. Besarnya rasio rata-rata industri adalah 0,3. Jadi semakin tinggi tingkat perputaran aktiva maka akan semakin tinggi pula laba yang akan diperoleh oleh perusahaan, sebaliknya Jadi semakin rendah perputaran aktiva maka akan semakin rendah pula laba yang akan diperoleh oleh perusahaan

3. Tingkat perhitungan dengan menggunakan ROE ( Return On Equity ) adalah rasio yang menunjukkan kemampuan perusahaan dalam menghasilkan laba 
bersih dengan menggunakan modal sendiri dan menghasilkan laba bersih yang tersedia bagi pemilik atau investor dalam laporan keuangan CV.Delta Agung Pratama tahun 2013 menunjukkan angka sebesar 16,56 yang berarti bahwa tingkat penghasilan dari modal yang diinvestasikan menghasilkan laba sebesar 16,56 Pada tahun 2014, rasio ini mengalami penurunan yang cukup besar yaitu sebesar 15,86 menjadi 0,7 yang berarti tingkat penghasilan dari modal yang diinvestasikan menghasilkan laba sebesar 0,7 Penurunan ini disebabkan atas berkurangnya laba bersih perusahaan sebesar Rp. 38.526.000 Pada tahun 2015, rasio ini kembali mengalami penurunan yaitu sebesar 0,14 menjadi 0,56 yang berarti tingkat penghasilan dari modal yang diivestasikan menghasilkan laba sebesar 0,56 Penurunan nilai rasio ini disebabkan atas kenaikan modal sendiri yang cukup besar dibandingkan kenaikan laba bersih.Dari perhitungan ROE perusahaan yang terjadi dari tahun 2013 sampai tahun 2015, dapat terlihat bahwa ROE perusahaan terus mengalami penurunan setiap tahun nya. Penurunan nilai ROE yang terlihat jelas yaitu pada tahun 2014 sebanyak 15,85 Tetapi kinerja perusahaan masih dapat dikatakan baik karena perusahaan tidak mengalami kerugian atas hal itu. Jika dilihat hasil keseluruhan yang telah diteliti berdasarkan rasio profitabilitas perusahaan CV. DELTA AGUNG PRATAMA cenderung berfluktuasi dan ketidak stabil sebagian besar rasio profitabilitasnya dibawah rata-rata rasio industri yang delah ditetapkan, dapat dibilang bahwa kinerja perusahaan termasuk kedalam kategori kurang baik dan tidak memenuhi standar rata - rata industry.

\section{DAFTAR PUSTAKA}

Afriyeni, A. Fernos, J (2018). Analisis Faktor-Faktor Penentu Kinerja Profitabilitas Bank Perkreditan Rakyat (BPR) Konvensional Di Sumatera Barat. Jurnal Benefita: Ekonomi Pembangunan Manajemen Bisnis Dan Akuntansi. Volume 3. No. 3. http://doi.org/10.22216/jbe.v3i3.3623

Arifin, I. Z., \& Marlius, D. (2017). Analisis Kinerja Keuangan PT. Pegadaian Cabang Ulak Karang. https://doi.org/10.31227/osf.io/n2peu

Bank Indonesia, 1992, UU No. 7 tahun 1992, tentang Perbankan, Jakarta. 1998, UU No. 10 tahun 1998, tentang perubahan terhadap UU No. 7 tahun 1992, Jakarta.

Handayani, M., \& Marlius, D. (2017). Analisis Tingkat Kesehatan PT. BPR Batang Kapas. https://doi.org/10.31227/osf.io/bq48z

Harnanto, 1991, “Anlisis Laporan Keuangan", Edisi 4, UPP AMP YKPN, Yogyakarta.

Jusuf, Haryono, AL. “Dasar - Dasar Akuntansi”. Yogyakarta: STIE YKPN 
Ikatan Akuntan Indonesia, Pernyataan Standar Akuntansi Keuangan No. 1, Revisi 2009, Dewan Standar Akuntansi Keuangan Ikatan Akuntan Indonesia, Jakarta, 2009

IAI, 1999, “Standar Akuntansi Keuangan”, Salemba Empat, Jakarta.

Kasmir. 2012. Analisis Laporan Keuangan. Edisi Ke 1-5. Jakarta: Rajawali Pers.

Dendawijaya, Lukman, 2003, “Manajemen Perbankan", Ghalia Indonesia, Jakarta.

.Munawir, 2000. Analisa Laporan Keuangan. Yogyakarta : Liberty

Munawir, S. 2004. Analisa Laporan Keuangan. Yogyakarta: Liberty.

Munawir, 2007. Analisa Laporan Keuangan. Yogyakarta

Putri, Y. A., \& Marlius, D. (2018). Analisis Tingkat Kesehatan Bank Pada PT. Bank Perkreditan Rakyat (BPR) Jorong Kampuang Tangah Pariaman Cabang Padang. https://doi.org/10.31227/osf.io/r98pv

Rahmayeli, D. S., \& Marlius, D. (2017). Analisis Kinerja Keuangan Pada PT. Bank Perkreditan Rakyat (BPR) Batang Kapas Pesisir Selatan. https://doi.org/10.31227/osf.io/sz5db

Sartono,Agus. 2005. Manajemen Keuangan. Yogyakarta: BPFE

Sugiono, Arief dan Edy Untung. 2008. Panduan Praktis Dasar Analisa Laporan Keuangan. Jakarta: PT. Grasindo

Weygandt, 2008. Analisa Laporan Keuangan. Jilid 2, Jakarta. 